\title{
Erratum to: Molecular Organization of 5S Ribosomal DNA of Deschampsia antarctica
}

\author{
O. O. Ishchenko ${ }^{a}$, I. I. Panchuk ${ }^{a}$, I. O. Andreev ${ }^{b}$, V. A. Kunakh ${ }^{b}$, and R. A. Volkov, * \\ ${ }^{a}$ Yuriy Fedkovych Chernivtsi National University, Chernivtsi, 58012 Ukraine \\ ${ }^{b}$ Institute of Molecular Biology and Genetics, National Academy of Sciences of Ukraine, Kyiv, 03143 Ukraine \\ *e-mail: r.volkov@chnu.edu.ua \\ Submitted January 9, 2019; accepted for publication January 9, 2019
}

DOI: $10.3103 / \mathrm{S} 0095452719010146$

The title of the article should read as follows:

Molecular Organization of 5S Ribosomal DNA of Deschampsia antarctica

The original article can be found online at https://doi.org/10.3103/S0095452718060105 